\title{
Buku Seribu Kutu Buku
}

P. Swantoro, Dari Buku ke Buku: Sambung Menyambung Menjadi Satu (Jakarta: Kepustakaan Populer Gramedia bekerjasama dengan Rumah Budaya TeMBI, 2002), xxv + 435 halaman; gambar, daftar pustaka, indeks.

Ketika memperkenalkan istilah dialektometri, Jéan Seguy (1971) mengawalinya dengan pertanyaan sekaligus pembelaan, "Jika ada ekonometri dan sosiometri, mengapa tidak ada dialektometri?" Retorika semacam itu mungkin dapat juga digunakan untuk mengawali pembicaraan mengenai buku yang sangat menarik ini. "Jika ada Pulo Seribu, Candi Sewu, Gunung Sewu, dan kaki seribu, mengapa tidak ada buku seribu?"

Satu hal yang pasti adalah, semua kata yang bergabung dengan seribu atau setwu itu, tidak satu pun yang jumlahnya seribu. Tampaknya itu merupakan ungkapan tradisional untuk menggambarkan sesuatu yang sangat banyak.

Demikian juga halnya dengan buku yang sebenarnya hanya satu ini. Mengapa buku ini patut disebut buku seribu?

Sebagaimana diungkapkan oleh Jakob Oetama yang menulis "Pengantar", dalam karya P. Swantoro ini,"Setiap kali muncul, suatu peristiwa atau komentar bukan saja disebutkan oleh siapa, tetapi juga sekaligus dalam penerbitan apa, siapa pengarangnya, siapa penerbitnya, kapan diterbitkan, dan halaman berapa" (h.xiii). Hal itu kemudian lebih ditegaskan oleh penulisnya sendiri, dengan mengatakan, "Buku ini lahir dari sebuah buku; bermula dari rasa heran seorang kakek, mengapa sebuah buku yang sering dilihat-lihatnya ketika masih di sekolah dasar, tidak jarang masih muncul dalam ingatannya. Padahal buku kepunyaan bapak ini sudah lama tidak ada, dan bapak pun sudah lama tiada" (h. xix).

Jadi, melalui karyanya ini penulis mengajak kita, terutama mereka yang tertarik pada sejarah dan masalah kesejarahan, untuk bersamanya mengembara "menembus waktu" masa lampau Nusantara. Sambil secara merendah penulis menyatakan bahwa ia "bukanlah seorang peneliti dan bukan pula seorang ilmuwan", penulis berhasil mengajak pembaca mengikuti "perkelanaan memori si kakek" (h. xxiii) itu.

Hasilnya? Dengan hanya membaca buku yang satu ini, pembaca akan memperoleh gambaran, baik secara umum maupun, dalam hal tertentu, secara khusus, mengenai apa yang pernah dilakukan para tokoh yang pernah meneliti relung sejarah, masyarakat, dan kebudayaan Nusantara masa lampau maupun masa yang lebih muasir.

Walaupun sudah sejak awal penulis mengatakan bahwa apa yang disajikannya itu "nampaknya tidak ada hubungannya satu sama lain," nyatanya ancang-ancang yang mengawali tiap bab justru memberikan gambaran betapa sebenarnya apa yang disajikannya itu saling terkait, memperlihatkan hubungan yang sangat erat. Itu jugalah barangkali yang mendorongnya untuk memberikan subjudul Sambung-menyambung menjadi satu itu. Sebagai contoh, Bab 2 yang dijuduli "Penulis buku pertama tentang 
PKI", mengetengahkan lagi apa yang pernah disampaikannya dalam Bab 1 "Bermula dari gambar berwarna" tentang buku yang dibaca dan diikhtisarkan itu. Begitulah terus, bab-bab berikut memperlihatkan hubungan dengan bab-bab sebelumnya.

Karena buku ini bukan buku sejarah, bukan merupakan kesalahan jika penyampaian bacaannya kepada pembaca tidak kronologis dari yang tertua sampai yang termuda. Namun, untuk bagian-bagian tertentu justru terlihat bahwa kronologi itu sebenarnya dipertahankannya sepanjang tidak "mengganggu" pengelanaan memorinya. Dalam hal ini, buku yang diikhtisarkan itu ditata demikian rupa dari yang paling tua hingga yang paling muda sejauh hal itu berkenaan dengan suatu topik khusus yang dikemukakannya. Dengan demikian, yang terjadi memang bukan kronologi dalam kisah sejarah, melainkan kronologi dalam kisah penerbitan buku yang dibacanya. Justru inilah yang merupakan sumbangan terbesar karya ini. Pembaca menjadi tidak terlalu repot mengurutkan kapan sebuah tulisan peneliti tertentu, karena hal itu sudah dengan sangat tertib dan rapi disajikan oleh penulis.

Tentu saja, dalam setiap karya selalu ada cacat atau kekurangannya. Namun, sekali lagi, jika pun buku ini mengandung cacat atau kekurangan, sebenarnya itu bukan pula kesalahan penulis. Dari semua buku yang dibicarakannya itu, sejauh menyangkut masa yang lebih kemudian, jangkauan dapat dikatakan meliputi seluruh Indonesia atau Nusantara. Namun, jika pembicaraan menyangkut masa yang jauh lebih tua, terlihat kecenderungan bahwa penulis memusatkan perhatiannya hanya kepada apa yang ditulis mengenai atau apa yang terjadi di Jawa. Hal itu bukan kesalahan karena penulis adalah seorang yang berlatar budaya Jawa sehingga bahkan hal itu merupakan suatu keuntungan. Artinya, beruntunglah mereka yang berlatar budaya Jawa, memiliki seorang "kutu buku" sehingga pengetahuan mengenai apa dan siapa orang dan budaya Jawa terselamatkan.

Dalam pada itu, "kepincangan" itu-jika memang itu kepincangantidak pula mustahil sebagai akibat kurangnya perhatian dan minat para peneliti yang menerbitkan karyanya berkenaan dengan masyarakat dan budaya daerah lain dibandingkan dengan apa yang telah mereka lakukan mengenai kebudayaan Jawa. Maka, karena buku ini menguraikan apa yang dilakukan para peneliti itu melalui buku dan karya tertulis mereka lainnya, sekali lagi, bukan kesalahan penulis jika sebagian buku ini mengesankan "terlalu jawa." Justru yang perlu dipacu adalah kegiatan penelitian mengenai masyarakat dan budaya daerah lain.

Mudah-mudahan dalam masa dekat, akan muncul buku serupa yang memuat tulisan mengenai masyarakat dan budaya daerah Batak, Aceh, Bali, dan daerah lainnya. 